survive they must make profit (or surplus, call it what one will) and charge for subscriptions in advance, so creating a cash reserve at the beginning of each year. As charitable institutions, in Britain they have substantial tax advantages. Moreover, many learned societies, both in Britain and the United States, still prefer to publish their journals through the commercial sector, rather than go it alone. Naïveté is unlikely to be the only reason.

At Blackwell's we have surveyed our top ten commercial publishers, and our top ten learned societies who publish independently; for the international subscription agents those two groups

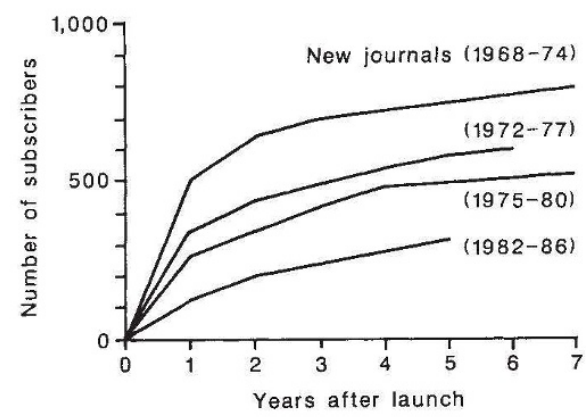

Fig. 1 Decline in circulation figures for new journals. (From A. Stevens Learned Publishing 2, 1-7; 1989.)

will represent a large proportion of their turnover, and their lists include a high proportion of primary journals. For 1989 over 1988 (not taking account of exchangerate variations) the commercial publishers increased their prices by 10.57 per cent, the learned societies by 10.40 per cent. Nor are overall prices notably different $£ 207.78$ for commercial publishers, $£ 217.85$ for learned societies.

I referred earlier to a 'crisis', which seems to me to be not over-stating the case - something, at some stage, has surely got to give in the dissemination of information through journals. Various courses of action are being advocated. More careful use of the present system by evaluating usage of individual titles against their price, replacement of expensive journals with cheaper ones, encouraging scholars not to serve on the editorial boards of journals that do not adopt realistic pricing policies and, in the longer term, the establishment of an informationclearing house to give libraries access to pricing policies, current journal rates, and proposed acquisitions and cancellation plans of other libraries. More radical would be the adoption of alternative forms of communication, in particular those employing electronics.

Meantime the demand to publish grows. No one - not least the scientific community - seems prepared to give way first.

John B. Merriman is Director of the Periodicals Division, B. H. Blackwell Ltd, POBox 40, Hythe Bridge Street, Oxford OX1 2EU, UK.

\title{
New journals review 1989
}

THE following explanation is offered to those wishing to know the basis on which the journals mentioned in the following pages were chosen for review.

In Nature's previous journal supplements*, two principles determined the time criteria for a publication to be eligible for review in a particular year. First, that at least four different issues should have been published, to give reviewers a reasonable sample on which to base a judgement. Second, that most new journals start as quarterlies though they often later become more frequent.

Thus in last year's review supplement journals first appearing between June 1986 and May 1987 were considered for review. The first date was carried forward from the previous year; the second meant that four issues of a quarterly would (in principle) be available to reviewers at the time of commissioning reviews in June 1988.

Publishers and others have pointed out that journals with a schedule more frequent than quarterly could hardly count as 'new' under this system, in terms of the numbers of issues published, by the time they came to be reviewed. So for 1989 the time criteria were changed - any journal published after May 1987 and with four issues available in May 1989

\section{Reviews index}

Acta Seismologica Sinica

Advanced Drug Delivery Reviews

Advanced Materials

AI \& Society

Anthrozoös

Autoimmunity

Biomedical and Environmental Sciences

Chemical Research in Toxicology

Chinese Journal of Biochemistry \& Biophysics

Computers in Physics

Current Opinion in Immunology

Cytotechnology

Earthquake Research in China

FASEB Journal

Geomorphology

Genomics

Glia

Historical Biology

International Journal of Expert Systems

International Journal of Modern Physics B

International Journal of Pattern Recognition and Artificial Intelligence

International Journal on the Unity of the Sciences

Journal of Autoimmunity

Journal of Chemical Neuroanatomy Journal of Drug Development
356

356

352

370

353

359

361

352

362

358

354

361

365

368

367

366

353

354

357 was eligible for review.

Other criteria were that the journal should appear at least three times a year, and that the main language used should be English. Abstracts publications and newsletters are not reviewed. Several titles eligible for review are not covered here for one reason or another, and a list of them appears on p. 370.

The brief given to reviewers was to limit themselves to comment on the publications sent to them, and to avoid discussion of general questions of periodical publishing. Opinions expressed in the reviews are based on a sample of issues, and apply to mid-1989 at the latest. As in previous years, the preponderance of journals in the biological sciences reflects the bias of material submitted for review.

Details of editors and frequency of publication, and the subscription rates appearing at the top of each review, are given in most instances for 1990. This information is not complete in all cases, and readers interested in subscribing to a particular journal should check the rates with the publisher concerned.

*See Nature 335, 459-478 (1988); 329, 357-376 (1987); 323, 359-379 (1986); 317, 293-308 (1985); 311, 309-330 (1984); 305, 477-497 (1983); 299, 491-514 (1982); and 293, 341-369 (1981).

Journal of Evolutionary Biology 363

Journal of Insect Behavior 362

Journal of Molecular Recognition $\quad 357$

Journal of Paleolimnology 360

Journal of Petroleum Science \& Engineering

364 Journal of Photochemistry and Photobiology B: Biology

Journal of Psychopharmacology

Journal of South American Earth Sciences

Journal of Superconductivity

Materials Science \& Engineering B

Modern Physics Letters B

Molecular Carcinogenesis

Molecular Microbiology

Natural Hazards

Neural Networks

Neuron

Neuropsychopharmacology

NMR in Biomedicine

Nonlinearity

Physica C: Superconductivity

364

368

369

368

359

Physics World

The Plant Cell

Protein Sequence \& Data Analysis

Regional Immunology

Science as Culture

Sexual Plant Reproduction

Superconductor Science and

Technology

Virus Genes

Visual Neuroscience 